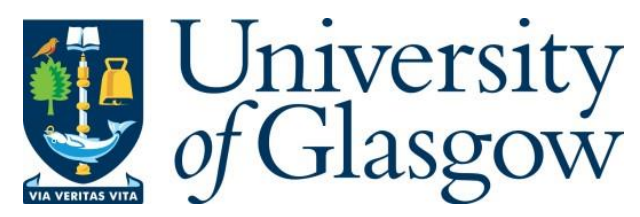

Delles, C., Li, H. and Touyz, R. M. (2020) ACE2 the Janus-faced protein - from cardiovascular protection to severe acute respiratory syndrome-coronavirus and COVID19. Clinical Science, 134(7), pp. 747-750.

There may be differences between this version and the published version. You are advised to consult the publisher's version if you wish to cite from it.

http://eprints.gla.ac.uk/213481/

Deposited on: 7 April 2020

Enlighten - Research publications by members of the University of Glasgow http://eprints.gla.ac.uk 


\title{
ACE2 the Janus-faced protein - from cardiovascular protection to severe acute respiratory syndrome (SARS)-Coronavirus and COVID-19
}

\author{
Rhian M Touyz ${ }^{1}$, Hongliang $\mathrm{Li}^{2}$, Christian Delles ${ }^{1}$ \\ ${ }^{1}$ Institute of Cardiovascular and Medical Sciences, University of Glasgow, UK; ${ }^{2}$ Institute of \\ Model Animal of Wuhan University, Wuhan, China.
}

Short title: ACE2- a multifunctional protein

Key words: Angiotensin, ACE, coronavirus, hypertension, renin angiotensin system, cardiovascular, COVID-19, SARS-CoV, SARS-CoV-2, ACE2 receptor

\section{Correspondence:}

Rhian M Touyz MBBCh, PhD, FRCP, FRSE.

Institute of Cardiovascular \& Medical Sciences

BHF Glasgow Cardiovascular Research Centre

University of Glasgow

126 University Place, Glasgow G12 8TA

Tel: + 44 (0)141330 7775/7774; Fax: + 44 (0)141 330-3360

Email: Rhian.Touyz@glasgow.ac.uk

Angiotensin converting enzyme 2 (ACE2) is a key element in the protective arm of the renin angiotensin system (RAS) $(1,2)$. It was discovered 20 years ago when it was found to possess over $60 \%$ similarity to ACE $(3,4)$. However, the active sites of ACE and ACE2 differ and accordingly, ACE inhibitors do not inhibit activity of ACE2 (5). ACE2 is a glycoprotein metalloprotease that exists in 2 forms: membrane-bound and soluble $(3,4,6)$. The membrane- 
bound form contains a transmembrane domain that anchors its extracellular domain to the plasma membrane. In its soluble form, it is cleaved and secreted as the N-terminal ectodomain and is found in very low concentrations in the circulation. The significance of circulating ACE2 is unclear, although levels may be increased in disease (diabetes, CKD, hypertension) (4,5). ACE2 has multiple substrates including kinins, apelin, neurotensin, dynorphin, ghrelin, amyloid and angiotensins (1-4). The best known function of ACE2 is to act as the physiological counterbalance of ACE providing homeostatic regulation of angiotensin II (Ang II) by converting Ang I to Ang-(1-9), and by converting Ang II to Ang(1-7), which is tissue-protective (7) (figure). ACE2 is expressed in organs important in blood pressure regulation (vessels, heart, kidney) as well as in the ovaries, testes, small intestine and lungs $(1-4,7)$.

Besides its enzymatic function, ACE2 has noncatalytic actions including the regulation of renal amino acid transport, intestinal neutral amino acid transport and pancreatic insulin secretion $(1,2)$ (Figure). Some of these effects are mediated through collectrin, a homologue of ACE2 (8-10). Moreover, it acts as a receptor for some coronaviruses $(\mathrm{CoV})(11,12)$. In 2003 severe acute respiratory syndrome (SARS) coronavirus (SARS-CoV) was identified as a novel respiratory pathogen leading to a global outbreak of SARS, and in 2012 a new CoV was shown to cause Middle-East respiratory syndrome (MERS) (13,). In 2019, SARS-CoV-2

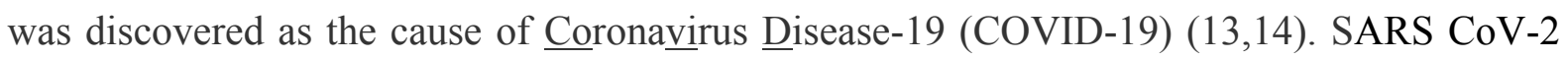
infection is initiated through inoculation of the respiratory tract mucosa using ACE2 acting as the functional receptor for cell entry, a process involving the serine protease TMPRSS2 (1520). Viraemia and replication in the lung, and possibly the gastrointestinal tract, follows.

The global impact of COVID-19 has been massive, touching everybody in some way or another. Following the first cases in Wuhan, reported in December 2019 (21), the infection 
spread rapidly until in March 2020, the World Health Organization (WHO) declared COVID19 a pandemic (22). To date $\left(23^{\text {rd }}\right.$ March 2020) WHO statistics indicate that more than 14,500 people in 190 countries/areas/territories have died from SARS-CoV-2. These numbers are increasing daily and will continue to multiply over the next weeks and months. The exact source of COVID-19 is still unknown, although the natural host of the virus is thought to be bats (based on virus genome sequencing) and/or turtles, snakes, and pangolins (23-25). There has been great progress in delineating the global epidemiology of the disease, tracking of infected individuals and defining the clinical features that characterise the acute respiratory disease $(26,27)$. However there is still a paucity of information on the molecular mechanisms whereby SARS-CoV-2 causes the disease and how host-pathogen interactions and host immune responses occur. While ACE2 and TMPRSS2 have been identified as part of the molecular machinery linked to SARS-Cov-2 effects, and have been suggested as putative therapeutic targets (15-20), there are still many unknowns about the underlying biology of the system. There is an urgent need to better understand the basic science of SARS-Cov-2-ACE2, so that disease-specific antiviral therapies can be developed.

Considering the important role of the RAS in the pathophysiology of hypertension and cardiovascular and renal disease (28), it has been suggested that ACE inhibitors and Ang II receptor blockers (ARBs) may increase the risk of COVID-19 infection by upregulating ACE2 $(29,30)$. On the other hand, it has been proposed that inhibitors of the RAS, particularly ARBs, may actually have therapeutic benefit in COVID-19 by targeting the host response to the virus (31). This is based on the fact that i) ARBs increase ACE2 expression/activity leading to increased production of Ang-(1-7), which is tissue-protective, and ii) ARBs inhibit Ang II-induced inflammation and acute injury in the lungs $(31,32)$. However, to date there is no convincing clinical evidence linking ACE inhibitors and/or ARBs to COVID-19 severity and mortality and further clinical research is needed (33). 
In only 2 decades, ACE2 has emerged as an important Janus-faced multifunctional protein: while it promotes cardiovascular health (through its tissue-protective actions) it also facilitates the devastations of SARS-Cov-2 infectivity responsible for the COVID-19 pandemic. It has also been suggested as a potential therapeutic target for SARS-CoV-2 (3436). To celebrate the 20-year discovery of ACE2, Clinical Science will publish a focused issue on 'ACE2- a multifunctional protein', guest edited by Prof M. Bader, Prof A. Turner and $\operatorname{Dr}$ N. Alenina. This issue will include state of the art review articles and research papers addressing the molecular and cellular biology, regulation and (patho)physiological functions of ACE2 in health and disease. This is perfectly aligned with the mission of the journal, which is to translate molecular bioscience and experimental research into medical insights to advance human health.

\section{Acknowledgements}

The authors thank Dr Livia Camargo for helping with the schematic. RMT is funded by a grants from the British Heart Foundation (CH/12/4/29762; RE/18/6/34217).

\section{Declarations}

Nil

\section{Figure legend}

ACE2 is a multifunctional protein. ACE2 has enzymatic (catalytic) and non-enzymatic (noncatalytic) functions. As a key element of the protective axis of the renin angiotensin system (RAS) it is responsible for production of Ang-(1-7) and Ang-(1-9). The major non-catalytic functions include renal amino acid transport, intestinal neutral amino acid transport and pancreatic insulin secretion.

\section{References}


1. Santos RAS, Oudit GY, Verano-Braga T, Canta G, Steckelings UM, Bader M. The renin-angiotensin system: going beyond the classical paradigms. Am J Physiol Heart Circ Physiol. 2019; 316(5):H958-H970.

2. Bitker L, Burrell LM. Classic and Nonclassic Renin-Angiotensin Systems in the Critically Ill. Crit Care Clin. 2019; 35(2):213-227.

3. Donoghue M, Hsieh F, Baronas E, Godbout K, Gosselin M, Stagliano N, Donovan M, Woolf B, Robison K, Jeyaseelan R, Breitbart RE, Acton S. A novel angiotensin-converting enzyme-related carboxypeptidase (ACE2) converts angiotensin I to angiotensin 1-9. Circ Res 2000; 87: E1-E19.

4. Tipnis SR, Hooper NM, Hyde R, Karran E, Christie G, Turner AJ. 2000. A human homolog of angiotensin-converting enzyme. Cloning and functional expression as a captopril-insensitive carboxypeptidase. J Biol Chem 2000; 275:33238-33243.

5. Turner AJ, Tipnis SR, Guy JL, Rice G, Hooper NM. ACEH/ACE2 is a novel mammalian metallocarboxypeptidase and a homologue of angiotensin-converting enzyme insensitive to ACE inhibitors. Can J Physiol Pharmacol. 2002; 80(4):346-53.

6. Kuba K, Imai Y, Penninger JM. Multiple functions of angiotensin-converting enzyme 2 and its relevance in cardiovascular diseases. Circ J. 2013; 77(2):301-8.

7. Santos RAS, Sampaio WO, Alzamora AC, Motta-Santos D, Alenina N, Bader M, Campagnole-Santos MJ. The ACE2/Angiotensin-(1-7)/MAS Axis of the ReninAngiotensin System: Focus on Angiotensin-(1-7). Physiol Rev. 2018; 98(1):505-553.

8. Hashimoto T, Perlot T, Rehman A, Trichereau J, Ishiguro H, Paolino M, Sigl V, Hanada T, Hanada R, Lipinski S, Wild B, Camargo SM, Singer D, Richter A, Kuba K, Fukamizu A, Schreiber S, Clevers H, Verrey F, Rosenstiel P, Penninger JM. ACE2 
links amino acid malnutrition to microbial ecology and intestinal inflammation. Nature. 2012; 487(7408):477-81.

9. Danilczyk U, Sarao R, Remy C, Benabbas C, Stange G, Richter A, Arya S, Pospisilik JA, Singer D, Camargo SM, Makrides V, Ramadan T, Verrey F, Wagner CA, Penninger JM. Essential role for collectrin in renal amino acid transport. Nature. 2006; 444(7122):1088-91.

10. Zhang Y, Wada J. Collectrin, a homologue of ACE2, its transcriptional control and functional perspectives. Biochem Biophys Res Commun. 2007;363(1):1-5.

11. Li W, Moore MJ, Vasilieva N, Sui J, Wong SK, Berne MA, Somasundaran M, Sullivan JL, Luzuriaga K, Greenough TC, Choe H, Farzan M. Angiotensin-converting enzyme 2 is a functional receptor for the SARS coronavirus. Nature. 2003; $426(6965): 450-4$

12. Hamming I, Timens W, Bulthuis ML, Lely AT, Navis G, van Goor H. Tissue distribution of ACE2 protein, the functional receptor for SARS coronavirus. A first step in understanding SARS pathogenesis. J Pathol. 2004; 203(2):631-7.

13. Guan Y, Zheng BJ, He YQ, Liu XL, Zhuang ZX, Cheung CL, Luo SW, Li PH, Zhang LJ, Guan YJ, Butt KM, Wong KL, Chan KW, Lim W, Shortridge KF, Yuen KY, Peiris JS, Poon LL. Isolation and characterization of viruses related to the SARS coronavirus from animals in southern China. Science. 2003;302(5643):276-8.

14. Zaki AM, van Boheemen S, Bestebroer TM, Osterhaus AD, Fouchier RA. Isolation of a novel coronavirus from a man with pneumonia in Saudi Arabia. N Engl J Med. 2012;367(19):1814-20.

15. Walls AC, Park YJ, Tortorici MA, Wall A, McGuire AT, Veesler D. Structure, Function, and Antigenicity of the SARS-CoV-2 Spike Glycoprotein. Cell. 2020; pii: S0092-8674(20)30262-2. 
16. Yan R, Zhang Y, Li Y, Xia L, Guo Y, Zhou Q. Structural basis for the recognition of the SARS-CoV-2 by full-length human ACE2. Science. 2020. pii: eabb2762.

17. Chen Y, Guo Y, Pan Y, Zhao ZJ. Structure analysis of the receptor binding of 2019nCoV. Biochem Biophys Res Commun. 2020; pii: S0006-291X(20)30339-9.

18. Wrapp D, Wang N, Corbett KS, Goldsmith JA, Hsieh CL, Abiona O, Graham BS, McLellan JS. Cryo-EM structure of the 2019-nCoV spike in the prefusion conformation. Science. 2020;367(6483):1260-1263.

19. Wan Y, Shang J, Graham R, Baric RS, Li F. Receptor Recognition by the Novel Coronavirus from Wuhan: an Analysis Based on Decade-Long Structural Studies of SARS Coronavirus. J Virol. 2020; 94(7). pii: e00127-20.

20. Hoffmann M, Kleine-Weber H, Schroeder S, Krüger N, Herrler T, Erichsen S, Schiergens TS, Herrler G, Wu NH, Nitsche A, Müller MA, Drosten C, Pöhlmann S. SARS-CoV-2 Cell Entry Depends on ACE2 and TMPRSS2 and Is Blocked by a Clinically Proven Protease Inhibitor. Cell. 2020. pii: S0092-8674(20)30229-4.

21. Zhou P, Yang XL, Wang XG, Hu B, Zhang L, Zhang W, Si HR, Zhu Y, Li B, Huang CL, Chen HD, Chen J, Luo Y, Guo H, Jiang RD, Liu MQ, Chen Y, Shen XR, Wang X, Zheng XS, Zhao K, Chen QJ, Deng F, Liu LL, Yan B, Zhan FX, Wang YY, Xiao GF, Shi ZL. A pneumonia outbreak associated with a new coronavirus of probable bat origin. Nature. 2020; 579(7798):270-273.

22. WHO. https://www.who.int/emergencies/diseases/novel-coronavirus-2019

23. Li B, Si HR, Zhu Y, Yang XL, Anderson DE, Shi ZL, Wang LF, Zhou P. Discovery of Bat Coronaviruses through Surveillance and Probe Capture-Based Next-Generation Sequencing. mSphere. 2020; 5(1). pii: e00807-19.

24. Zhang T, Wu Q, Zhang Z. Probable Pangolin Origin of SARS-CoV-2 Associated with the COVID-19 Outbreak. Curr Biol. 2020. pii: S0960-9822(20)30360-2. 
25. Liu Z, Xiao X, Wei X, Li J, Yang J, Tan H, Zhu J, Zhang Q, Wu J, Liu L. Composition and divergence of coronavirus spike proteins and host ACE2 receptors predict potential intermediate hosts of SARS-CoV-2. J Med Virol. 2020; doi: 10.1002/jmv.25726.

26. Guo YR, Cao QD, Hong ZS, Tan YY, Chen SD, Jin HJ, Tan KS, Wang DY, Yan Y. The origin, transmission and clinical therapies on coronavirus disease 2019 (COVID19) outbreak - an update on the status. Mil Med Res. 2020;7(1):11.

27. Huang C, Wang Y, Li X, Ren L, Zhao J, Hu Y, Zhang L, Fan G, Xu J, Gu X, Cheng Z, Yu T, Xia J, Wei Y, Wu W, Xie X, Yin W, Li H, Liu M, Xiao Y, Gao H, Guo L,Xie J, Wang G, Jiang R, Gao Z, Jin Q, Wang J, Cao B. Clinical features of patients infected with 2019 novel coronavirus in Wuhan, China. Lancet. 2020; 395(10223):497-506.

28. Arendse LB, Danser AHJ, Poglitsch M, Touyz RM, Burnett JC Jr, Llorens-Cortes C, Ehlers MR, Sturrock ED. Novel Therapeutic Approaches Targeting the ReninAngiotensin System and Associated Peptides in Hypertension and Heart Failure. Pharmacol Rev. 2019;71(4):539-570.

29. Zheng YY, Ma YT, Zhang JY, Xie X. COVID-19 and the cardiovascular system. Nat Rev Cardiol. 2020; doi: 10.1038/s41569-020-0360-5.

30. Esler M, Esler D. Can angiotensin receptor-blocking drugs perhaps be harmful in the COVID-19 pandemic? J Hypertens. 2020; doi: 10.1097/HJH.0000000000002450.

31. Gurwitz D. Angiotensin receptor blockers as tentative SARS-CoV-2 therapeutics. Drug Dev Res. 2020. doi: 10.1002/ddr.21656.

32. Fedson DS, Opal SM, Rordam OM. Hiding in Plain Sight: an Approach to Treating Patients with Severe_COVID-19 Infection. mBio. 2020 Mar 20;11(2). pii: e00398-20. 
33. Kuster GM, Pfister O, Burkard T, Zhou Q, Twerenbold R, Haaf P, Widmer AF, Osswald S. SARS-CoV2: should inhibitors of the renin-angiotensin system be withdrawn in patients with COVID-19? Eur Heart J. 2020; pii: ehaa235.

34. Batlle D, Wysocki J, Satchell K. Soluble angiotensin-converting enzyme 2: a potential approach for coronavirus infection therapy? Clin Sci (Lond). 2020;134(5):543-545.

35. Zhang H, Penninger JM, Li Y, Zhong N, Slutsky AS. Angiotensin-converting enzyme 2 (ACE2) as a SARS-CoV-2 receptor: molecular mechanisms and potential therapeutic target. Intensive Care Med. 2020; doi: 10.1007/s00134-020-05985-9.

36. Santos RAS, Oudit GY, Verano-Braga T, Canta G, Steckelings UM, Bader M. The renin-angiotensin system: going beyond the classical paradigms. Am J Physiol Heart Circ Physiol. 2019; 316(5):H958-H970. 